\title{
How Do Managers Hedge Against Oil ETFs in the COVID-19 Pandemic?
}

\author{
Yuhan $\mathrm{Gao}^{1, \dagger}$, Yi Wang ${ }^{2, \dagger}$, Yongxi Wang ${ }^{3, *}, \dagger$ \\ ${ }^{1}$ Commerce, University of Toronto, Mississauga, L5B0K4, Canada \\ ${ }^{2}$ D'Amore-McKim School of Business, Northeastern University, Boston, MA 02115, United States \\ ${ }^{3}$ College of Letters and Science, University of California, Santa Barbara, CA 93106, United States \\ *Corresponding author. Email: Yongxi@ucsb.edu \\ ${ }^{\dagger}$ These authors contributed equally.
}

\begin{abstract}
During the COVID-19 pandemic, the oil price fluctuated significantly due to dramatic changes in oil supply and oil demand, which leads to high volatility in oil-related assets and induces an urgent need to alleviate risks. We use a market neutral strategy to assess the results of hedging against oil ETFs. By selecting several representative ETFs among currency ETFs and gold ETFs, we made trades with an oil ETF based on historical data, respectively. The results indicate that as signalled by positive return, hedging by selected ETFs indeed helps portfolio managers in managing risks of oil-related assets during the pandemic and using an Australian currency-related ETF to hedge against a crude oil ETF has the best performance, as indicated by the highest return, compared with other hedge tools in this paper. Meanwhile, the results provide portfolio managers with some thoughts on the selection or priority of hedging tools, that is, putting currencies-related ETFs in the first place and then commodities-related ETFs.
\end{abstract}

Keywords: COVID-19, crude oil, currency, gold, hedge

\section{INTRODUCTION}

In December, the first case of a cluster of pneumonia occurred in the city of Wuhan, Hubei Province, China. The cause was identified as a new coronavirus. The disease has spread quickly worldwide with the ceaseless human-to-human transmission, and the World Health Organization WHO announced on March 11, 2020, that the disease was a pandemic [1]. The impact of COVID-19 is significant to almost every industry as people, the major source of inputs, are required to work from home to reduce the speed of disease transmission. The market of crude oil and stock is one of them. Research has shown that the impact of COVID-19 on the volatility of the oil and stock markets is even more severe than the impact of the financial crisis in 2008 [2]. Figure 1 shows the daily price of West Texas Intermediate (WTI) futures, a benchmark of U.S. crude oil prices. On April 20, 2020, the price of WTI even reached a negative number of -36.98 dollars per barrel, which was an unprecedented event. Therefore, the purpose of this paper is to analyse hedging results between crude oil and other types of assets, including currencies and commodities, and determine which asset would be optimal to use as a hedging tool against the volatility of crude oil.

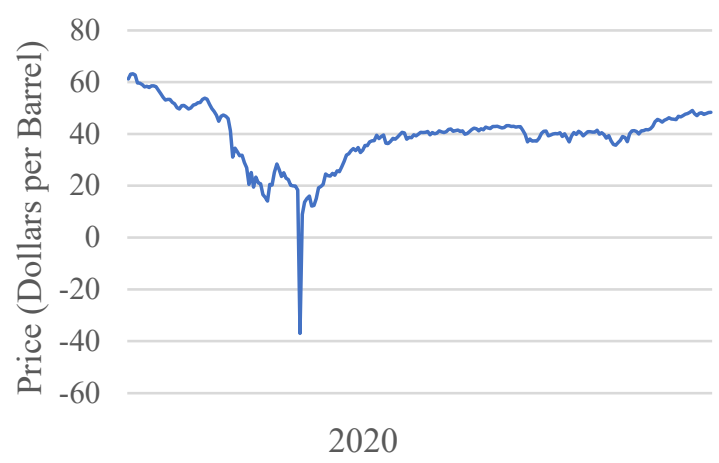

Figure 1. Price of WTI oil in 2020 caption content. Notes: Data comes from the U.S. Energy Information Administration. We abstract prices from 01/02/2020 to $12 / 31 / 2020$.

Due to the pandemic, both the demand and supply side of crude oil is largely affected. On the demand side, the fear of being diagnosed with COVID-19 within an enclosed space and the fact that some countries such as China and the United Kingdom suffered lockdown to 
control the spread of the pandemic decreased the number of airline passengers as well as flights. The issue of travel restrictions and border shutdowns played an important role in the decrease in flight volume. Since February, there had been fewer flights than in the same month in previous years. The reduction was the largest in May 2020: a total $68.9 \%$ reduction compared to May 2019 [3]. On the supply side, workers for petroleum extraction and drilling were resting at home, and it was unknown when they could go back to work as variants continued to occur. Over 300 drills were shut down between November 2019 and the end of April 2020 [4]. A non-optimistic situation of the pandemic in the Middle East also affects oil-exporting. In addition to the supply and demand of crude oil, the failure to reach the OPEC agreement led to the Russia-Saudi Arabia oil price war, causing a significant decline in the price of crude oil by approximately $26 \%$ [4]. Since the longevity of the impact of the pandemic on financial markets is unknown, and the price fluctuation of crude oil itself makes crude oil-related assets volatile, hedging against the volatility of these assets is necessary.

The rest of the study is structured as follows. Section 2 describes data and the hedging technique. Section 3 represents trading results and analyses the results. In Section 4, the conclusion will be made, and future research directions will be stated.

\section{DATA AND RESEARCH METHOD}

\subsection{Data}

To assess the performance of currencies and commodities as hedge tools against crude oil-related assets, we collect information about different ETFs. Table 1 summarizes starting price, ending price, mean, variance, beta (5Y monthly) and annual total return in 2020 for each ETF.

Table 1. Summarization of ETFs.

\begin{tabular}{ccccccc}
\hline ETF & $\begin{array}{c}\text { Price } \\
\text { as of 03/09/2020 }\end{array}$ & $\begin{array}{c}\text { Price } \\
\text { as of 12/14/20 }\end{array}$ & Mean & Variance & $\begin{array}{c}\text { Beta } \\
\text { (5Y Monthly) }\end{array}$ & $\begin{array}{c}\text { Annual Total } \\
\text { Return (2020) }\end{array}$ \\
\hline $\begin{array}{c}\text { United States Oil Fund LP } \\
\text { (USO) }\end{array}$ & $\$ 55.86$ & 32.17 & 1.32 & 3.15 & 2.77 & $-67.66 \%$ \\
$\begin{array}{c}\text { Invesco Currency Shares } \\
\text { Swiss Franc Trust (FXF) }\end{array}$ & $\$ 99.59$ & $\$ 102.83$ & 0.3132 & 0.1771 & 4.32 & $8.28 \%$ \\
$\begin{array}{c}\text { Invesco Currency Shares } \\
\text { Australian Dollar Trust } \\
\text { (FXA) }\end{array}$ & $\$ 65.93$ & $\$ 75.05$ & 0.4409 & 0.2814 & 15.85 & $9.41 \%$ \\
$\begin{array}{c}\text { Invesco DB US Dollar } \\
\text { Index Bearish Fund (UDN) } \\
\text { SPDR Gold Shares (GLD) }\end{array}$ & $\$ 55.86$ & $\$ 32.17$ & 0.2468 & 0.1012 & 0.37 & $6.20 \%$ \\
\hline
\end{tabular}

Notes: Mean is obtained by the sum of return deviations of US Oil and divided by the number of calculation points for the selected time horizon. Variance is calculated by the sum of the square root of actual returns deviation over the selected period divided by the number of points for the period. The annual total return is obtained from ETFs' 2020 data at Yahoo Finance.

We mark 24 Feb 2020 as the beginning day when COVID-19 began to receive international attention. On that day, the Team Leaders of the WHO-China Joint Mission on COVID-19 reported the main findings through their investigation and appealed to large scales of health measures [5]. However, our initial jet fuel price is the price on 9 March 2020. It usually takes some for people to realize the change of the situation and WHO announced guidance of 4 different transmission scenarios on 7 March [5]. The ending price is the price on 14 Dec 2020, the date when United Kingdom authorities reported A SARS-CoV-2-variant, which is a sign of a new round of the pandemic.

We collected the prices of different ETFs as of 7 March 2020 and as of 14 December 2020. We use United States Oil Fund LP (USO), which tracks the price of West Texas Intermediate Light Sweet Crude Oil (WTI). The reason we use WTI in our paper is that WTI is a benchmark in the oil market in North America and serves as a reference price for buyers and sellers of crude oil. WTI has been used as a benchmark since 1983 and gradually became a global indicator [6]. Figure 2 shows the price fluctuation of USO.

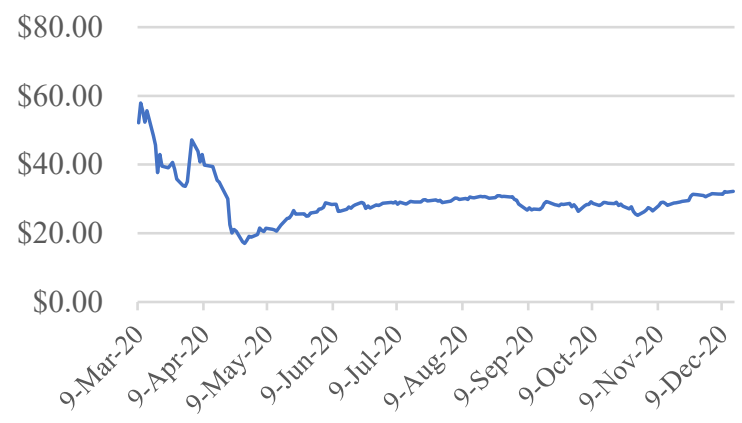

Figure 2. Price of United States Oil Fund LP (USO). Notes: Data from Yahoo Finance.

For currency hedging, we make trades from 3 perspectives. One is from the perspective of avoiding risks by currencies, and thus we use Invesco Currency shares Swiss Franc Trust (FXF), which tracks the price of the Swiss franc. The Swiss franc is known as a 
popular safe haven currency, shown in an article called "The Swiss Franc Safety Premium" by Jessica Leutert. Swiss Franc Safety Premium was found to be around $2.5 \%$ between early 1999 to mid 2011, and around $4.5 \%$ in these years, while up to $12.5 \%$ during the recent financial crisis. These results illustrate that the Swiss Franc can play a role as a safety haven [7]. From March 9, 2020, to December 14, 2020, FXF experienced minor price waves, and it showed an upward trend overall.

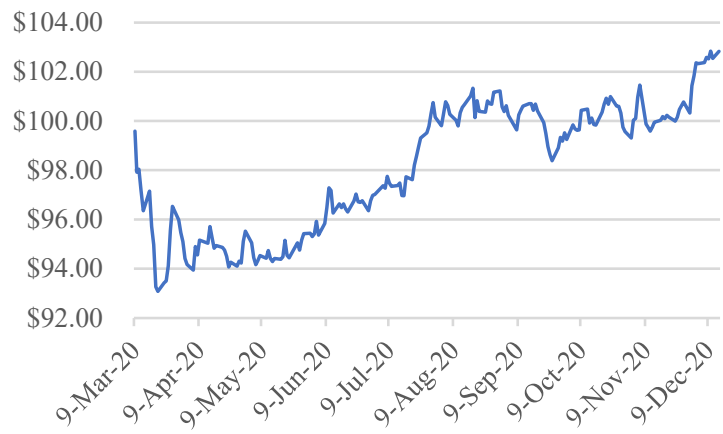

Figure 3. Price of Invesco Currency shares Swiss Franc Trust (FXF). Notes: Data from Yahoo Finance.

The second currency, ETF, is chosen based on its relationship with international trade. We use Invesco Currency shares Australian Dollar Trust (FXA), which reflects the price in U.S. dollars of the Australian dollar. The Australian Dollar is a mature internationalized currency. An internationalized currency can be traded freely against other currencies and used to denominate contracts, including bank accounts and bonds, outside its country of issue. The Australian Dollar trades much more in the global foreign exchange market than in the home economy. Moreover, the Australian dollar goes well beyond non-resident investment in the domestic bond market[8]. From March 9, 2020, to December 14, 2020, FXF experienced minor price waves, and it showed an upward trend overall.

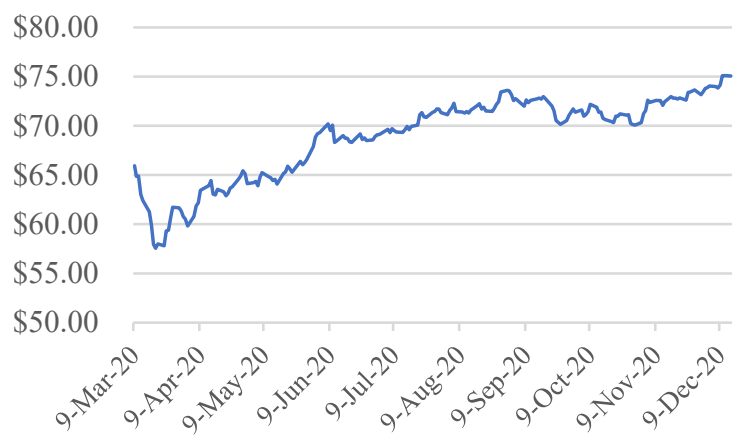

Figure 4. Price of Invesco Currency shares Australian Dollar Trust (FXA). Notes: Data from Yahoo Finance.

The last currency ETF we use is Invesco DB US Dollar Index Bearish Fund (UDN). It tracks the value of the U.S. dollar relative to a basket of the six major currencies - the euro, Japanese yes, British pound,
Canadian dollar, Swedish Krona and Swiss franc. The U.S. dollar is always used as the invoicing currency in global crude oil trading. Therefore, the dollar price of crude oil is significantly related to the fluctuations of the value of the U.S. dollar [9]. From March 9, 2020, to December 14, 2020, UDN experienced minor price waves, and it showed an upward trend overall.

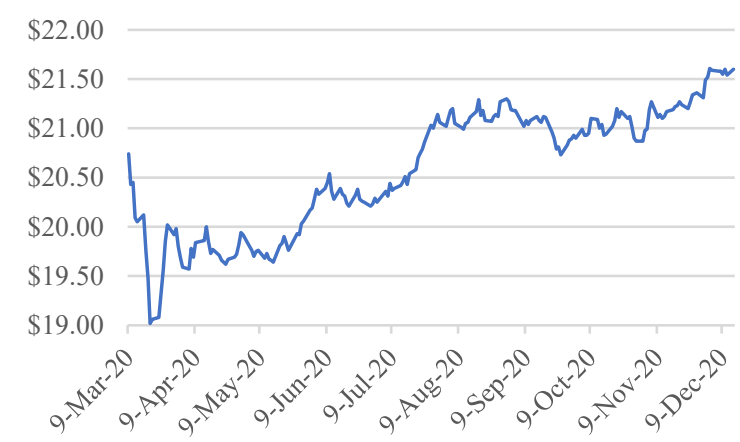

Figure 5. Price of Invesco DB US Dollar Index Bearish Fund (UDN). Note: Data from Yahoo Finance.

In addition to currencies, we use commodities as a hedging tool. SPDR Gold Shares (GLD), which tracks the price of gold bullion in the over-the-counter market, is a reasonable choice. Gold is considered as a safe haven. It is also used as a hedge against extreme stock market conditions [10].

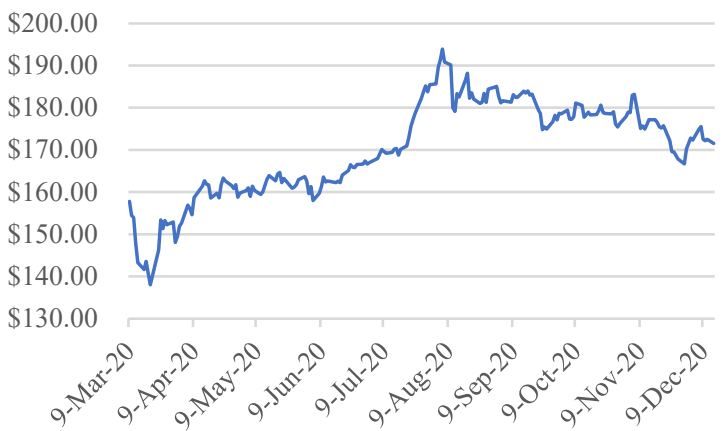

Figure 6. Price of SPDR Gold Shares (GLD). Notes: Data from Yahoo Finance.

\subsection{Methodology}

Due to the uncertainty in the market, we decided to use the market neutral strategy to hedge against the risk. The target of market neutral is to make the value of beta of the whole portfolio equal to zero. The beta of a company measures the systematic and the nondiversifiable risk of the stock. It also represents the measure of market risk or performance volatility related to the extent to which the return on security moves with that of the overall market. A beta greater than one implies that the stock is more volatile than the market, and a beta less than one means that the stock has low 
volatility. If the beta is less than zero, it indicates that the stock moves inversely with the market trend.

Based on the shock from the pandemic, we originally hypothesised that crude oil would decrease in value since there is a decreasing demand for oil worldwide. Therefore, we decided to take a short position on the oil ETF. Meanwhile, we observe that there is an increasing trend in the price of ETFs for gold and currency for those large oil-importing countries. Hence, we decided to take long positions on the ETF of gold and the currency ETFs for particular countries that are heavily affected by the oil prices to hedge against the risk.

To execute the market neutral strategy, the amount of ETFs in the portfolio would be an essential factor to consider. The formula to calculate the optimal amount of each individual ETF is defined in Eq. (1) and Eq. (2),

$-\beta_{A} \omega_{A}+\beta_{B} \omega_{B}=0$

$\omega_{A}+\omega_{B}=1$

in which the weights of each individual ETF in the portfolio $\left(w_{A}, w_{B}\right)$ are distributed based on the beta value of an ETF, and the total weight equals one. The total risk exposure of the trade should be 0 to get rid of the impact from external environments.

In addition, we estimate the return of the trade by using historical data. The return is calculated by the formula of Eq.(2), in which the original price when we purchase the ETF is denoted as $\mathrm{P}_{0}$ and the final price when we sell the ETF is denoted as $\mathrm{P}_{1}$. The total return is the weighted return of each ETF.

$$
\text { Return }=\frac{P_{1}-P_{0}}{P_{0}}
$$

\section{EMPIRICAL RESULTS AND DISCUSSION}

\subsection{Oil ETF and Currencies ETF}

Based on the uncertainty caused by COVID-19, the change in the price of crude oil would lead to a shock in the overall financial market. The relationship between oil and foreign exchange markets contributes to the volatility of those major oil-importing and oil-exporting countries [11]. As a result, the value of currency for large oil-importing countries such as the United States, France, Switzerland, and Australia are highly affected by the change in the crude oil markets. The results of the following three trades are generally consistent with other research.

In the first trade, we used a neutral market strategy to hedge between United States Oil Fund (USO) and Invesco Currency shares Swiss Franc Trust (FXF). We invested about $60 \%$ in crude oil. With the basic idea of taking a short position in the U.S oil fund, the profit and return are shown in Table 2. Most of the profits are generated from the short side of the trade, with an expected return of $27.11 \%$ for the whole portfolio. This implies that there would be a huge decline in the price of crude oil during the pandemic.

The second trade involves taking a long position in the Invesco Currency shares Australian Dollar Trust (FXA) and taking a short position in the United States Oil Fund (USO). We invested almost $85 \%$ in the short side of the U.S crude oil, which generated a return of $42.41 \%$, with a total profit of $\$ 250,406.72$ for the portfolio, as shown in Table 3. The result is similar since we generated most profit from the short side.

The last trade related to currency involves using the market neutral strategy by taking a long position in Invesco DB US Dollar Index Bearish Fund (UDN) and taking a short position in United States Oil Fund (USO) and indicated in Table 4 . Inversely, we invested $88 \%$ in the long position of the U.S dollar fund. However, the return on the whole portfolio is only $9.04 \%$ which is much less than the previous trades. A possible inference could be due to the influence on the extent of the COVID-19. The coronavirus crisis damaged the stock returns, which created a huge loss on the U.S financial markets [12]. Therefore, we could infer that the value of the U.S currency decreases much more than the decline in the price of crude oil. This concludes the result that the return from the long side is not quite obvious.

\subsection{Oil ETF and Gold ETF}

The last trade takes a long position in the SPDR Gold Shares (GLD) and short the United States Oil Fund (USO). The profit and return are shown in Table 5. Similarly to the previous trade with the U.S dollar, we invested $96 \%$ in the long side of the gold ETF, which generated the most profit for $\$ 1,495,801.12$. Since gold is considered a linked commodity with crude oil [13], it could be appropriate to hedge against the risk of crude oil, which could be the reason for the huge profit relative to the previous trades.

Table 2. Oil ETF and Swiss Currency ETF

\begin{tabular}{|c|c|c|c|c|c|c|c|c|c|}
\hline Trade & ETF & Beta & Position & $\begin{array}{c}\text { Price as } \\
\text { of } \\
03 / 09 / 20\end{array}$ & $\begin{array}{c}\text { Price as } \\
\text { of } \\
12 / 14 / 20\end{array}$ & Quantity & $\begin{array}{c}\text { Initial } \\
\text { Cost }\end{array}$ & Weight Profit/Loss & Return \\
\hline $\begin{array}{c}\text { Oil ETF } \\
\text { and Swiss }\end{array}$ & $\begin{array}{c}\text { Invesco } \\
\text { Currencyshares }\end{array}$ & 4.32 & Long & 99.59 & 102.83 & 3597 & 358225.23 & $0.3907 \quad 11654.28$ & $3.25 \%$ \\
\hline
\end{tabular}




\begin{tabular}{|c|c|c|c|c|c|c|c|c|c|c|}
\hline \multirow[t]{3}{*}{$\begin{array}{c}\text { Currency } \\
\text { ETF }\end{array}$} & $\begin{array}{c}\text { Swiss Franc Trust } \\
\text { (FXF) }\end{array}$ & & & & & & & & & \\
\hline & $\begin{array}{l}\text { United States Oil } \\
\text { Fund, LP (USO) }\end{array}$ & 2.77 & Short & 55.86 & 32.17 & 10000 & 558600 & 0.6092 & $236,900.00$ & $42.41 \%$ \\
\hline & Total & 0 & & & & & 916825.23 & 1 & $248,554.28$ & $27.11 \%$ \\
\hline
\end{tabular}

Table 3. Oil ETF and Australian Currency ETF

\begin{tabular}{|c|c|c|c|c|c|c|c|c|c|c|}
\hline Trade & ETF & Beta & Position & $\begin{array}{c}\text { Price as } \\
\text { of } \\
03 / 09 / 20\end{array}$ & $\begin{array}{c}\text { Price as } \\
\text { of } \\
12 / 14 / 20\end{array}$ & Quantity & $\begin{array}{c}\text { Initial } \\
\text { Cost }\end{array}$ & Weight & Profit/Loss & Return \\
\hline \multirow{3}{*}{$\begin{array}{l}\text { Oil ETF and } \\
\text { Australian } \\
\text { Currency } \\
\text { ETF }\end{array}$} & $\begin{array}{c}\text { Invesco } \\
\text { CurrencyShares } \\
\text { Australian Dollar } \\
\text { Trust (FXA) }\end{array}$ & 15.85 & Long & 65.93 & 75.05 & 1481 & 97642.33 & 0.1488 & 13506.72 & $13.83 \%$ \\
\hline & $\begin{array}{l}\text { United States Oil } \\
\text { Fund, LP (USO) }\end{array}$ & 2.77 & Short & 55.86 & 32.17 & 10000 & 558600 & 0.8512 & 236900 & $42.41 \%$ \\
\hline & Total & 0 & & & & & 656242.33 & & 250406.72 & $38.16 \%$ \\
\hline
\end{tabular}

Table 4. Oil ETF and US Currency ETF

\begin{tabular}{|c|c|c|c|c|c|c|c|c|c|c|}
\hline Trade & ETF & Beta & Position & $\begin{array}{c}\text { Price as of } \\
03 / 09 / 20\end{array}$ & $\begin{array}{c}\text { Price as of } \\
12 / 14 / 20\end{array}$ & Quantity & Initial Cost & Weight & Profit/Loss & Return \\
\hline \multirow{3}{*}{$\begin{array}{c}\text { Oil ETF and } \\
\text { US Currency } \\
\text { ETF }\end{array}$} & $\begin{array}{c}\text { Invesco DB US } \\
\text { Dollar Index } \\
\text { Bearish Fund } \\
\text { (UDN) }\end{array}$ & 0.37 & Long & 20.74 & 21.69 & 201637 & 4181951.38 & 0.8822 & 191555.15 & $4.58 \%$ \\
\hline & $\begin{array}{l}\text { United States } \\
\text { Oil Fund, LP } \\
\text { (USO) }\end{array}$ & 2.77 & Short & 55.86 & 32.17 & 10000 & 558600 & 0.1178 & 236900 & $42.41 \%$ \\
\hline & Total & 0 & & & & & 4740551.38 & 1 & 428455.15 & $9.04 \%$ \\
\hline
\end{tabular}

Table 5. Oil ETF and Gold ETF

\begin{tabular}{|c|c|c|c|c|c|c|c|c|c|c|}
\hline Trade & ETF & Beta & Position & $\begin{array}{c}\text { Price as of } \\
03 / 09 / 20\end{array}$ & $\begin{array}{c}\text { Price as of } \\
12 / 14 / 20\end{array}$ & Quantity & Initial Cost & Weight & Profit/Loss & Return \\
\hline \multirow{3}{*}{$\begin{array}{l}\text { Oil ETF } \\
\text { and Gold } \\
\text { ETF }\end{array}$} & $\begin{array}{l}\text { SPDR Gold } \\
\text { Shares (GLD) }\end{array}$ & 0.09 & Long & 157.81 & 171.54 & 108944 & 17192452.64 & 0.9685 & $1,495,801.12$ & $8.70 \%$ \\
\hline & $\begin{array}{l}\text { United States } \\
\text { Oil Fund, LP } \\
\quad \text { (USO) }\end{array}$ & 2.77 & Short & 55.86 & 32.17 & 10000 & 558600 & 0.0315 & $236,900.00$ & $42.41 \%$ \\
\hline & Total & 0 & & & & & $17,751,052.64$ & 1 & $1,732,701.12$ & $9.76 \%$ \\
\hline
\end{tabular}

\section{CONCLUSION}

We have presented hedging against a crude oil ETF by market neutral strategy and explained the relationship between hedging ETFs with crude oil. Then we conducted several trades based on historical prices of different ETFs. Our findings indicate that hedging properly against crude oil related assets can generate a positive return. Using an Australian currency-related ETF to hedge against a crude oil ETF has the best performance compared to other trades since it generates the largest return. We also find that using Swiss currency ETFs shows a favourable result. 
From a practical perspective, the findings can provide some ideas for portfolio managers to constrain risks. They could consider Australian currency ETFs when they are building portfolios for individual investors, especially during a usual period such as the COVID-19. In addition, if budgeting is limited, portfolio managers can prioritize hedging tools and give more weights to ETFs that potentially generate more profits.

Our research leaves at least two shortcomings. One is that we only use USO as our oil ETF, which may not be representative and sufficient to generate a strong result. Including another ETF that tracks Brent oil might be a reasonable solution as it is another leading global price benchmark for crude oil supply. The other shorting is that we only use one trading strategy. Even though we can better compare trading results among different ETFs by this method, using other strategies, such as momentum trade, may generate different results.

\section{REFERENCES}

[1] Sanyaolu, A., Okorie, C., Hosein, Z., Patidar, R., Desai, P., Prakash, S., Jaferi, U., Mangat, J., \& Marinkovic, A., Global pandemicity of COVID-19: situation report as of June 9, 2020, SAGE Journals, 2020, vol. 14, pp. 1-8. DOI: https://doi.org/10.1177/1178633721991260.

[2] Zhang, W., \& Hamori, S., Crude oil market and stock markets during the COVID-19 pandemic: Evidence from the US, Japan, and Germany, International Review of Financial Analysis, 2021, vol. $74, \quad 101702$. DOI: https://doi.org/10.1016/j.irfa.2021.101702.

[3] Sun X., Wandelt S., Zheng C., Zhang A., COVID19 pandemic and air transportation: Successfully navigating the paper hurricane, Journal of Air Transport Management, 2021, Vol. 94: 102062. DOI: https://doi.org/10.1016/j.jairtraman.2021.102062.

[4] Jefferson M., A crude future? COVID-19s challenges for oil demand, supply and prices, Energy Research \& Social Science, 2020, vol. 68, 101669.

DOI: https://doi.org/10.1016/j.erss.2020.101669.

[5] World Health Organization, Timeline: Who's Covid-19 response, 2021. Available at: https://www.who.int/emergencies/diseases/novelcoronavirus-2019/interactivetimeline?gclid=EAIaIQobChMI5f30v-o8gIVBcWWCh2zyQPiEAAYASAAEgKId_D_B wE\#!

[6] World Gold Council, Gold demand by country: Gold demand and supply statistics, 2021. Available at: https://www.gold.org/goldhub/data/goldsupply-and-demand-statistics.

[7] Leutert, J. The Swiss franc safety premium, Swiss Journal of Economics and Statistics, 2018, vol. 154, Article Number: $13 . \quad$ DOI: https://doi.org/10.1186/s41937-017-0014-7.

[8] McCauley, Robert N., Internationalising a currency: The case of the Australian dollar, BIS Quarterly Review, December 2006. Available at: https://ssrn.com/abstract=1632352.

[9] Zhang, Y., The links between the price of oil and the value of the US dollar, International Journal of Energy Economics and Policy, 2013, vol. 3, pp. 341-351. Available at: https://www.econjournals.com/index.php/ijeep/arti cle/download/546/307.

[10] Baur, D. G., Lucey, B. M., Is gold a hedge or a safe haven? An analysis of stocks, bonds and gold, The Financial Review, 2010, vol. 45, pp. 217-229. DOI: https://doi.org/10.1111/j.1540-6288.2010.00244.x.

[11] Thorbecke, W., The Impact of the COVID-19 pandemic on the U.S. economy: Evidence from the stock market, Journal of Risk and Financial Management, 2020, vol. 13, pp. 1-30. DOI: https://doi.org/10.3390/jrfm13100233.

[12] Reboredo, J., Is gold a hedge or safe haven against oil price movements? Resources Policy, 2013, vol. 38, pp. 130-137. DOI: https://doi.org/10.1016/j.resourpol.2013.02.003.

[13] Yun, W. and Jae Kim, H., Hedging strategy for crude oil trading and the factors influencing hedging effectiveness, Energy Policy, 2010, vol. 38, pp. 2404-2408. DOI: https://doi.org/10.1016/j.enpol.2009.12.032. 